\title{
Instabilities and deformation in the sedimentary cover on the upper slope of the southern Aquitaine continental margin, north of the Capbreton canyon (Bay of Biscay)
}

\author{
ELIANE GONTHIER ${ }^{1}$, PIERRE CIRAC ${ }^{1}$, JEAN-CLAUDE FAUGERES ${ }^{1}$, MATHIEU \\ GAUDIN ${ }^{1}$ MICHEL CREMER ${ }^{1}$ and JEAN-FRANÇOIS BOURILLET ${ }^{2}$
}

\author{
${ }^{1}$ Université Bordeaux I, Département de Géologie et Océanographie, UMR CNRS 5805-EPOC, 33405 Talence cedex, \\ France. E-mail: e.gonthier@epoc.u-bordeaux1.fr
} ${ }^{2}$ DRO/GM, IFREMER, BP 70, 29280, Plouzané, France.

\begin{abstract}
SUMMARY: Acoustic and core data have recently been collected on the shelf break and the upper part of the slope of the south Aquitaine continental margin. They reveal the major role played by mass-flow gravity processes in deposit erosion and redistribution, modelling of the sea-bed, and transfer of sediment toward the deep-sea. The study region is bounded in the south by the Capbreton canyon. The northern area, which shows a smooth morphology, is characterised by small-scale deformations due to sediment creep or low-amplitude slide processes. The deformations are associated with mini listric-like faults that bound packets of sediments in which the deposit geometry is typical of constructional sediment waves. These sediment waves result from the interaction of depositional and gravity deformation processes. In the southern area, closer to the canyon, wave-like structures are still present but mostly of smaller size. They only result from gravity deformation processes without any evidence of constructional processes. In the vicinity of the Capbreton canyon, the shelf break and upper slope have a much more uneven morphology with sedimentary reliefs, escarpments and depressions directed toward the canyon thalweg. The depressions look like slide scars, and could be the result of regressive slides initiated at the top of the canyon flank. The age of the sliding event responsible for the formation of the depression observed today could be middle to upper Quaternary. Since their formation, these depressions act as conduits that channel the transfer of shelf sediment into the canyon, as demonstrated by the occurrence of a meandering channel on the sea-floor of one depression.
\end{abstract}

Keywords: Bay of Biscay, canyon, continental slope, sediment wave, mass flows, sediment transfer.

RESUMEN: INESTABILIDADES Y DEFORMACIÓN EN LA CUBIERTA SEDIMENTARIA DE LA PARTE SUPERIOR DEL TALUD DEL MARGEN CONTINENTAl dE Aouitania, NORTE DEl CAÑón DE CAPBRETON (Golfo DE VizCAYA). - Se recogieron datos acústicos y de testigos (cores) en el límite de la plataforma y la parte superior del talud en el margen continental del sur de Aquitania. Estos datos revelan el importante papel que juegan los procesos de flujos en masa por gravedad en la erosión y redistribución de los depósitos, el modelado del lecho marino y la transferencia de sedimentos hacia el fondo del océano. La región de estudio está limitada al sur por el cañón de Capbreton. El área norte, que presenta una morfología suave, está caracterizada por deformaciones de pequeña escala debidas al arrastre de sedimentos o procesos de deslizamiento de baja amplitud. Las deformaciones están asociadas a mini fallas de tipo lístrico que delimitan bolsas de sedimentos en las cuales la geometría del depósito es típica de ondas de sedimento constructivas. Estas ondas sedimentarias resultan de la interacción de los procesos de deformación deposicionales y por gravedad. En el área sur, cerca del cañón, están todavía presentes estructuras similares a ondas, pero la mayor parte son de pequeño tamaño. Estas estructuras son el resultado de los procesos de deformación por gravedad sin ninguna evidencia de procesos constructivos. En las proximidades del cañón de Capbreton, el margen continental y el talud superior tienen una morfología mucho más desigual con relieves sedimentarios, escarpaduras y depresiones dirigidas hacia el talweg del cañón. Las depresiones semejan marcas de deslizamientos y pueden ser el resultado de deslizamientos regresivos iniciados en la parte superior de los flancos del cañón. Los eventos de deslizamiento responsables de la formación de las depresiones observadas actualmente podrían datarse en el Cuaternario medio o superior. Desde su formación, estas depresiones funcionan como conductos que canalizan la transferencia de sedimentos de plataforma hacia el cañón, tal y como demuestra la presencia de un canal con meandros en el fondo de una de estas depresiones.

Palabras clave: Golfo de Vizcaya, cañón, talud continental, onda de sedimento, flujos en masa, transferencia de sedimento. 


\section{INTRODUCTION}

The shelf break and the upper slope of continental margins constitute a key zone for the transfer of sediments from the inner shelf to the deep sea. However, the sedimentary processes allowing this transfer are still poorly understood. Several types of currents can interact in this zone: tidal- or climaticinduced shelf currents, superficial geostrophic currents, internal waves and gravity flows (from hyperpycnal currents to mass movements) (Shepard and Marshall, 1978; in Stanley and Moore, 1983; in Swift et al., 1991; Nittrouer and Wright, 1994; Johnson and Baldwin, 1996; Viana et al., 1998, among many others)

In this part of the margin, an important sedimentary process is the reworking of sediments. It is favoured by the steep slopes $\left(>2^{\circ}\right)$ encountered in both active and passive margins and associated with regions with a high sedimentation rate. The presence of gullies or canyon heads leads to a high instability of the deposits and a massive erosion on the flank of these features (Mulder and Cochonnat, 1996; Berné et al., 1999; Babonneau et al., 2002; Ercilla et al., 2002; Greene et al., 2002, among many others published recently). These processes are efficient agents for the transfer toward the deep of sediments deposited on the outer shelf. Tectonic activity, movements along faults, and diapirism activity, sometimes associated with fluid circulation and often underlined by pockmarks (Hovland and Judd, 1988; Baraza and Ercilla, 1996; Le Moigne, 1999), are also favourable factors for sediment reworking.

The sediment reworking involves various processes, ranging from low velocities over short distances in the case of creeping (Hill et al., 1982; Syvitsky et al., 1987; Whitham, 1993) or sheardominated retrogressive failure (Correggiari et al., 2001) to block slides or slumps over a variable distance that can evolve to debris flows and turbidity currents (Lewis, 1971; Lowe, 1982; Martinsen, 1989; Mulder et Cochonnat, 1996; among many others). The gravity reworked deposits often have undulated morphologies similar to depositional sed-

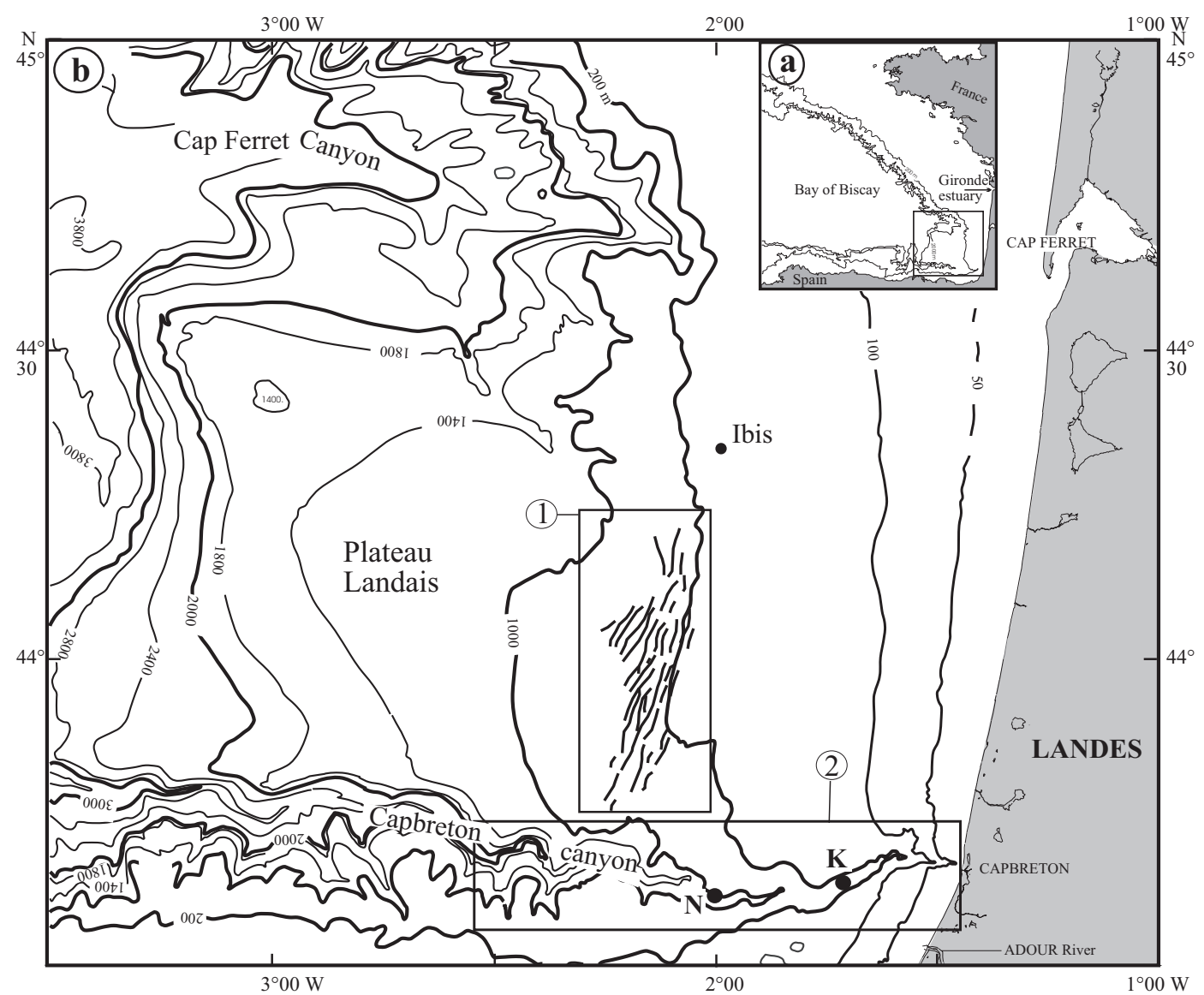

FIG. 1. - Location map of the study area. 1a: location of the south Aquitaine margin; 1b: location of the continental slope studied, in the black rectangle the sediment waves area deduced from acoustic imagery (in Faugères et al., 2002) and the Cap Breton canyon (rectangle 2)

corresponding to the bathymetric map realised during the Itsas cruise, see Fig. 2. - N: Nesteroff et al., 1968 core, - K: Oxybent core. 


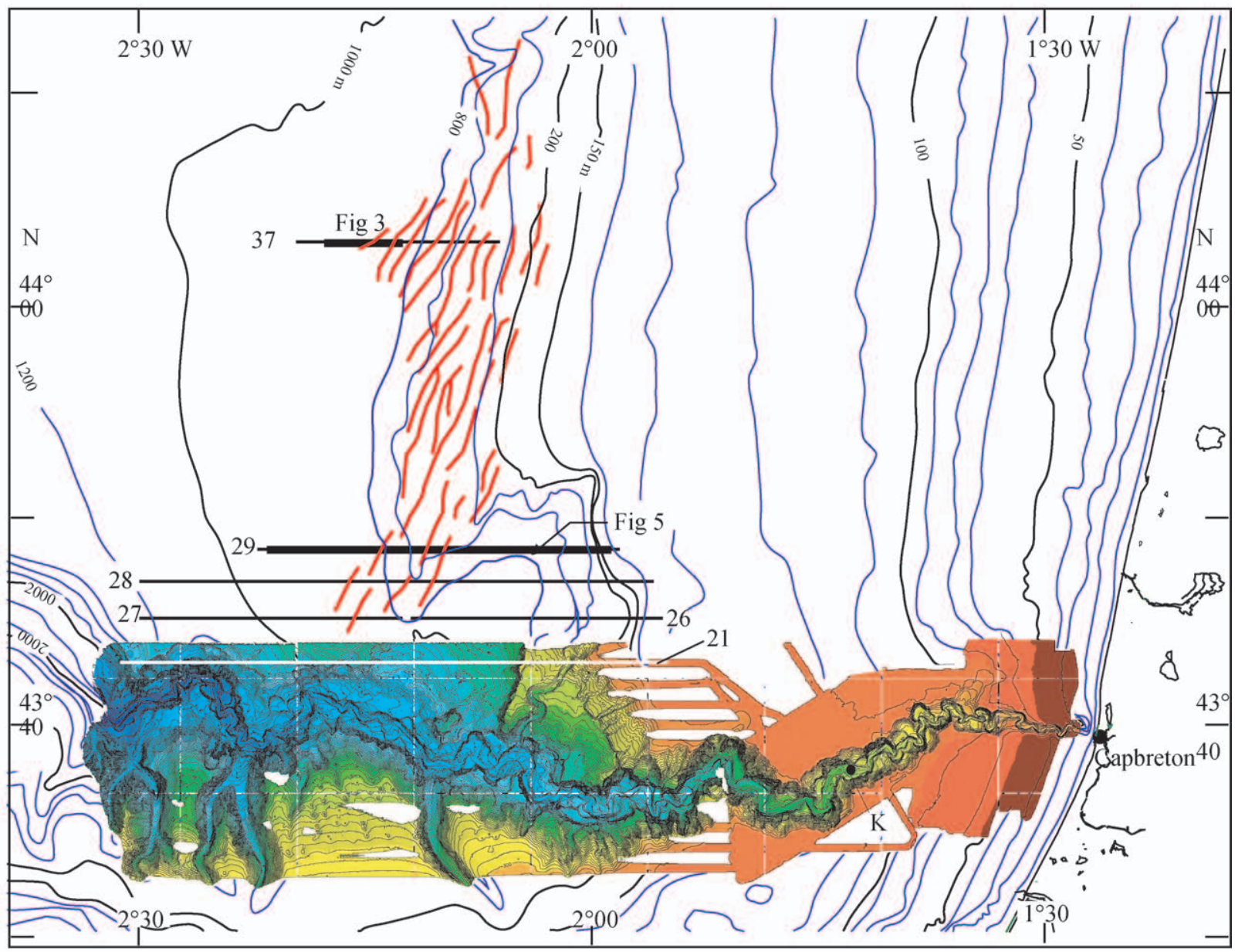

FIG. 2. - Southern part of the Aquitaine margin and detailed map of the Capbreton Canyon (rectangle 2 on Fig 1). Black lines: seismic data, itsr21, itsr26 to itsr29 and itsd37 (chirp 2-7 kHz) and location of Figures 3 and 5.

imentary waves. This implies that their gravity origin is often difficult to establish only from seismic data (O'Leary and Laine, 1996; Gardner et al., 1999; Faugères et al., 2002).

The sediment waves resulting from the deformation of sediment during the slides correspond to extensional and compressional structures (Martinsen and Bakken, 1990). They are located between two listric faults and formed by sedimentary beds that are either stretched and tilted like antidunes (extension context) or folded and thrusting downstream (compressional ripples).

Such sediment wave structures are well developed on the shelf break of the southern part of the Aquitaine margin (Fig. 1) and are associated with gravity processes (Kenyon et al., 1978; Faugères et al., 2002). In this study, mainly based on recent acoustic data (Figs. 1 and 2), the authors give a more detailed interpretation of these structures together with a new highlight on mass sediment transfer processes. The analysis will focus on the recent processes of deformation, destabilisation and remobilisation of sediments from the shelf break and upper slope (between 250 and $1000 \mathrm{~m}$ ).

\section{MORPHOTECTONIC CONTEXT}

The study area corresponds to the southern part of the Aquitaine continental margin developed between the Cap Ferret canyon to the north and the Capbreton canyon to the south (Figs. 1 and 2). In this region, the N-S upper slope that limits a 40 to 60 $\mathrm{km}$ wide continental shelf results from the progradation of sediments on a marginal plateau, the Landes plateau, located between 1000 and $2000 \mathrm{~m}$ depth. The dip of the upper slope decreases from $10^{\circ}$ upslope to less than $0.5^{\circ}$ downslope.

This region was submitted to active tectonic activity in the Cretaceous and Palaeogene periods, as well as more recently with Triassic salt diaper replay (Cholet et al., 1968; Valery et al., 1971; 
Kieken, 1973; Boillot et al., 1984). The Capbreton canyon (Dauvillier, 1961; Cirac et al., 2001) is a major morphological feature of the margin. It is incised in the colliding zone of the Aquitaine and Iberian plates, whose activity began in the midCretaceous in relation to the opening of the Bay of Biscay (Schoeffler, 1965; Boillot et al., 1974; 1984) and the formation of the Pyrenees.

Previous works have shown the presence of fields of kilometric sediment waves on the upper slope (side-scan sonar GLORIA, Stride et al, 1969; Kenyon et al., 1978). They were interpreted as the result of the deformation of superficial deposits due to slides. A new interpretation was recently proposed by Faugères et al., 2002: the waves affect a 250 to $500 \mathrm{~m}$ thick Plio-Quaternary sequence composed of four seismic units and are due to the interaction of gravity deformation and sedimentary construction.

\section{MATERIAL AND METHODS}

New data were recently acquired on the southern Aquitaine margin (Figs. 1 and 2):

- Backscatter imagery (Ifremer, mission ZeeGascogne I et II, 1992; 1993) on the upper slope for the major part of the study area, southern termination excepted.

- A detailed bathymetry of the Capbreton canyon from the head located in the inner part on the continental shelf down to the slope at 2500 m water depth (missions Itsas I-1999, multibeam bathymetry EM1000; Itsas II-2001, multibeam bathymetry EM300).

- More than $1000 \mathrm{~km}$ of sparker seismic profiles, 6 traces seismic profiles (profiles named itsr) and chirp $/ 2-7 \mathrm{kHz}$ (profiles named itsd) collected during the Itsas II cruise. Only the seismic profiles itsr21, itsr26 and itsr29 and the chirp profiles itsd37 and itsd27 to itsd29 are used in this paper;

- Gravity cores (Fig. 1), core K, Oxybent cruise, in Mulder et al., 2001 and cores N in Nesteroff et al., 1968.

\section{RESULTS AND INTERPRETATION}

In the study area, two regions located in the north and south can be distinguished according to the general morphology of the upper slope together with the sedimentary structures observed on the sea floor.

\section{The north region}

North of $43^{\circ} 55^{\prime} \mathrm{N}$ (Fig. 2) the continental shelf sea floor is flat and regular. The shelf break is well marked. The dip of the upper slope decreases rapidly with depth (more than $10^{\circ}$ upslope and $2^{\circ}$ at 600 $\mathrm{m}$ water depth, to less than $0.5^{\circ}$ below $850 \mathrm{~m}$ water depth). The upper slope morphology is characterised by the sedimentary waves studied by Faugères et al. (2002) from the Itsas I seismic data. The new echosounder profiles acquired during the Itsas II cruise confirm this interpretation.

In the upper sedimentary cover, from the four units (U1 to U4) described by Faugères et al., (2002), only the two most superficial, U3 and U4, are visible on the Itsd 37 profile (Fig. 3). These units are 80 to 100 thick (with $1500 \mathrm{~m} / \mathrm{s}$ for sound velocity in sediments). They may represent the last 500,000 to 800,000 years of sedimentation for an average sedimentation rate of $10 \mathrm{~cm}$ per 1000 years according to borehole data (Fig. 1, forage Ibis in Winnock, 1973) or from cores located north of the margin (Caralp, 1968, 1971; Duprat, 1983).

In both units, deposits show spectacular sediment wave geometries. However, the geometry in the units is different and indicates different formation processes.

In U3, waves result from the interaction of two processes: syn-sedimentary deformation and dynamic construction by currents. The first process induces micro-deformation and gaps in the seismic reflectors together with the presence of discontinuities between two adjacent waves. These discontinuities, interpreted as micro-listric faults, bound sedimentary packets due to stretching or gravityinduced tilting associated with a small-scale sliding along the slope (a few metres to tens of metres). This is the origin of the wave morphology of the second process, is underlined by downlap and toplap reflectors and plays a role in the greater thickness of the upstream flank and in the migration of the wave in this direction. The wave trough can be locally filled by onlapping deposits (Fig. 3).

This pattern confirms the complex origin of these structures in which deformation and construction processes interact and lead to an antidune-type of wave geometry (Faugères et al., 2002).

On the other hand, in the overlying U4 unit, the deposits blanket the undulated morphology inherited from U3. There are neither deformation nor construction processes but only a uniform 


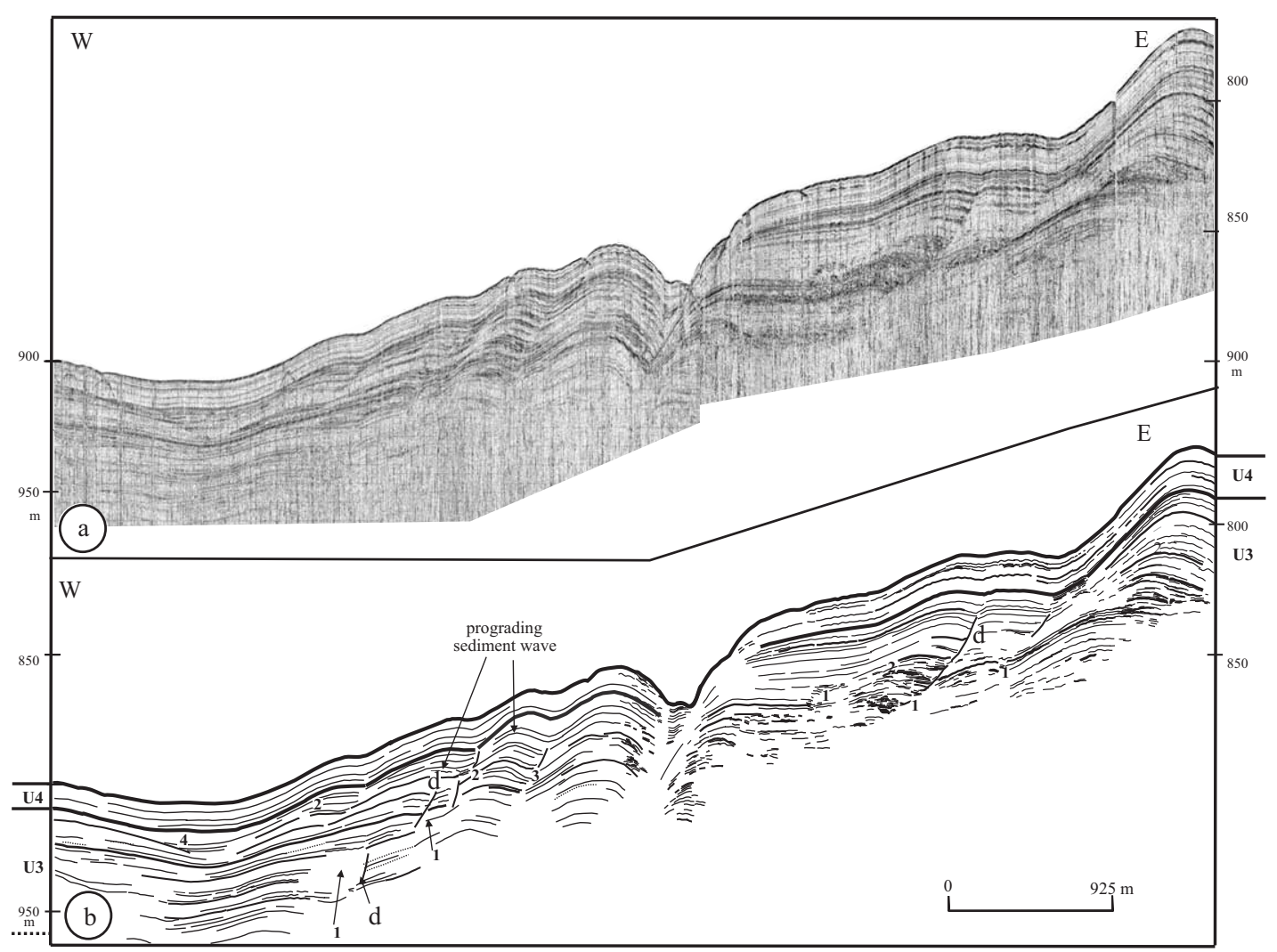

FIG. 3. - Profile itsd37 (chirp 2-7 kHz) crossing the north part, see location Figure 3. a: profile seismic Chirp 2-7kHz; b: interpretation (1: micro-deformation associated with disorganised reflectors; 2: toplap reflexion; 3: downlap reflexion; 4: onlap reflexion underlining building processes; d: discontinuities or micro-faults between two sediment waves.

hemipelagic/pelagic sedimentation covering the entire wave field.

The northern part of the study area is hence characterised by limited destabilisation processes restricted to some period of time (during U3 for example). This will be discussed in 5.2.

\section{The south region}

South of $44^{\circ} 55^{\prime} \mathrm{N}$ (Figs. 2 and 4 ) the dip of the upper slope is greater than in the north region and is directed either to the west and the Landes plateau $\left(2^{\circ}\right.$ to $\left.3^{\circ}\right)$ or to the south toward the Capbreton Canyon (usually greater than $5^{\circ}$ ). Near the Capbreton Canyon, the sea floor morphology shows NW-SE to NNW-SSE scarps that delimit NE-SW troughs. The northern flank of the canyon constitutes the southern limit of the study area.

\section{The Capbreton Canyon}

The Capbreton Canyon constitutes a major area for shelf sediment transport onto the abyssal plain (Figs 2 and 4). It deeply incises the continental shelf with its head located $400 \mathrm{~m}$ off the coastline. The flanks and the axial meandering channel are subjected to active erosion by turbidity currents or mass wasting (Nesteroff, 1968; Cirac et al., 2001). Cores collected in the late sixties (Nesteroff, 1968) sampled quaternary turbidites resulting from the downcanyon transport of shelf sediment or slope sediments. Recent studies show that this sedimentary dynamics is still active nowadays. In 2001 Mulder et al. showed that the 1999 Christmas storm that affected the western coast of France generated a turbidity current responsible for a $30 \mathrm{~cm}$ thick turbidite.

The troughs bordering the northern flank of the Capbreton Canyon

The northern part of the Capbreton Canyon has two depressions (Fig. 4) that open toward the southwest into the canyon. Their morphologies are similar to large slide scars affecting the northern flank of the canyon.

To the east, the first depression (1, Fig. 4) is located close to the shelf break; its western flank is 


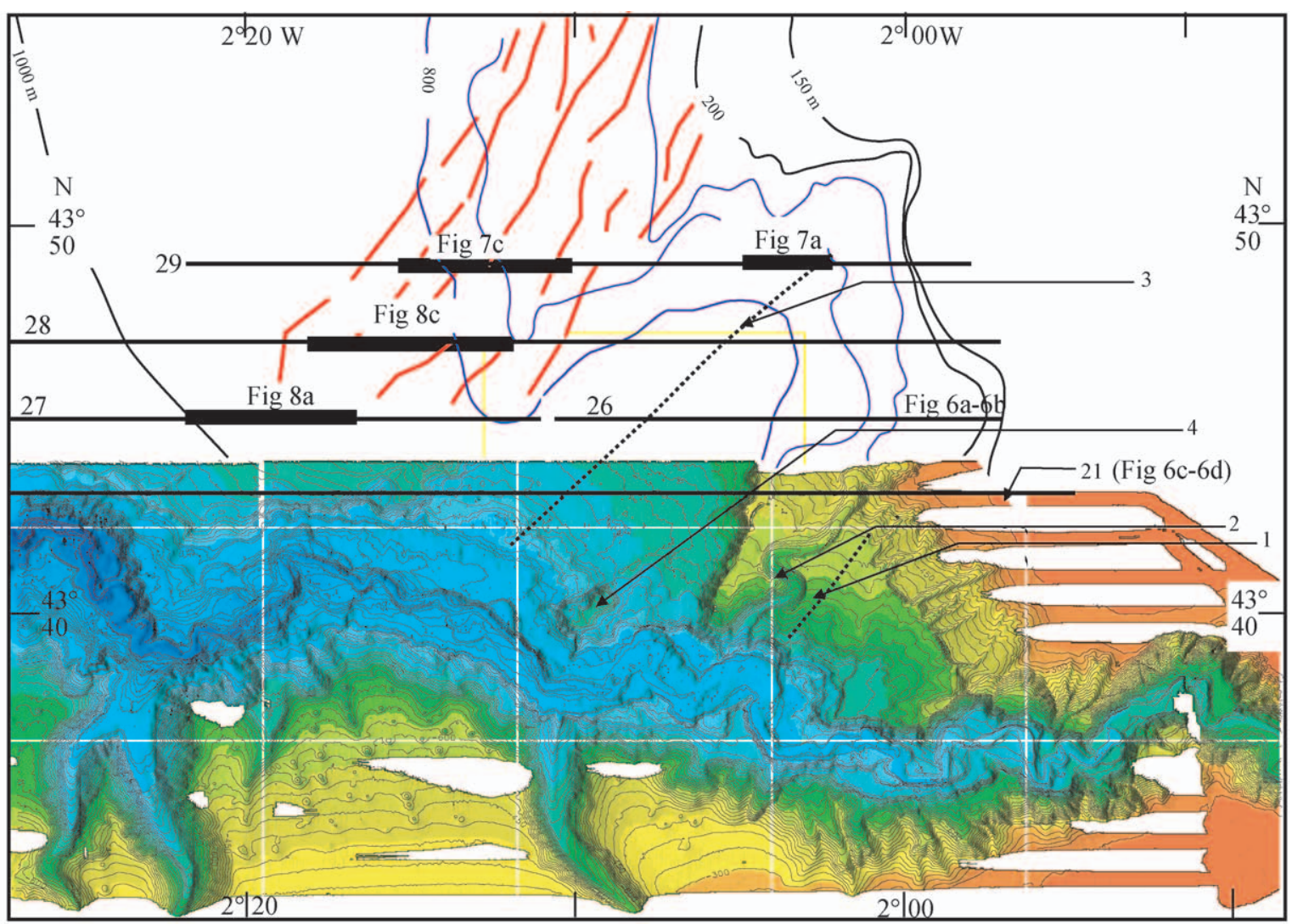

FIG. 4. - Detail of the downstream part of Capbreton Canyon showing two depressions situated on the north flank and separated by escarpments NNE-SSW or NW-SE (1: south depression; 2: meandriform channel; 3: western depression; 4: residual sedimentary relief, (slide deposits or relict deposits after erosion?). Location of seismic profiles itsr21 to itsr29 and Figures 7a, 7c, 8a and 8c.

dissected by a clear meandering channel suggesting recent turbidity current activities. However, this channel stands a few tens of metres above the canyon axial channel (Fig. 4). To the west, the second depression, wider than the first one (3, Figs 4, 5 and 6), has a rough sea-floor without channel. Small topographic highs within the depression (4, Fig. 4) are interpreted either to be areas preserved from erosion, or slide-deposit remnants that did not reach the canyon.

The eastern flank of the western depression, which is $350 \mathrm{~m}$ high (Figs. 5 and $6 \mathrm{a}$ and b) is clearly eroded at its lower part with an irregular slope, whereas at its higher part the slope is regular in accordance with a prograding shelf edge. The western flank is lower $(200 \mathrm{~m})$ and displays erosive features and chaotic deposits on every seismic profile (Figs. 5 and 6d). In Figure 5, the seismic sequence observed in the depression shows two subsequences separated by a major discontinuity. The lower sub-sequence (E.i., Fig. 5) with a filled channel is inferred to be Tertiary in age. The upper subsequence (E.s., Fig. 5), Plio-Quaternary in age, exhibits flat reflectors becoming progressively undulating topward. The western depression cut this upper sequence during an erosive phase discussed below. The last erosive surface linked to this phase (s.e. Fig. 5) is blanketed by a thin bed of draping sediments (Figs. 5 and 7a). However, this bed locally shows few gravity destabilisations (slide or tilted blocks), as on the eastern flank of the depression (Fig. 7a).

\section{Sedimentary levees and waves}

West to the western depression (Fig. 5), the deposits of the top of the upper sub-sequence form a relief gently dipping to the west, whereas the slope to the east is steeper and shorter. They correspond to a seismic unit thinning westward and showing a more or less undulating wave covered by draping reflectors. This unit mimics a sedimentary levee built up by turbidity currents (Normark et al., 1980; Cremer, 1983; Bouma, 1985; Normark and Piper, 1991). Its thickness (50 to $150 \mathrm{~m}$ ) and geometry are similar to those of units 3 and 4 observed in the 


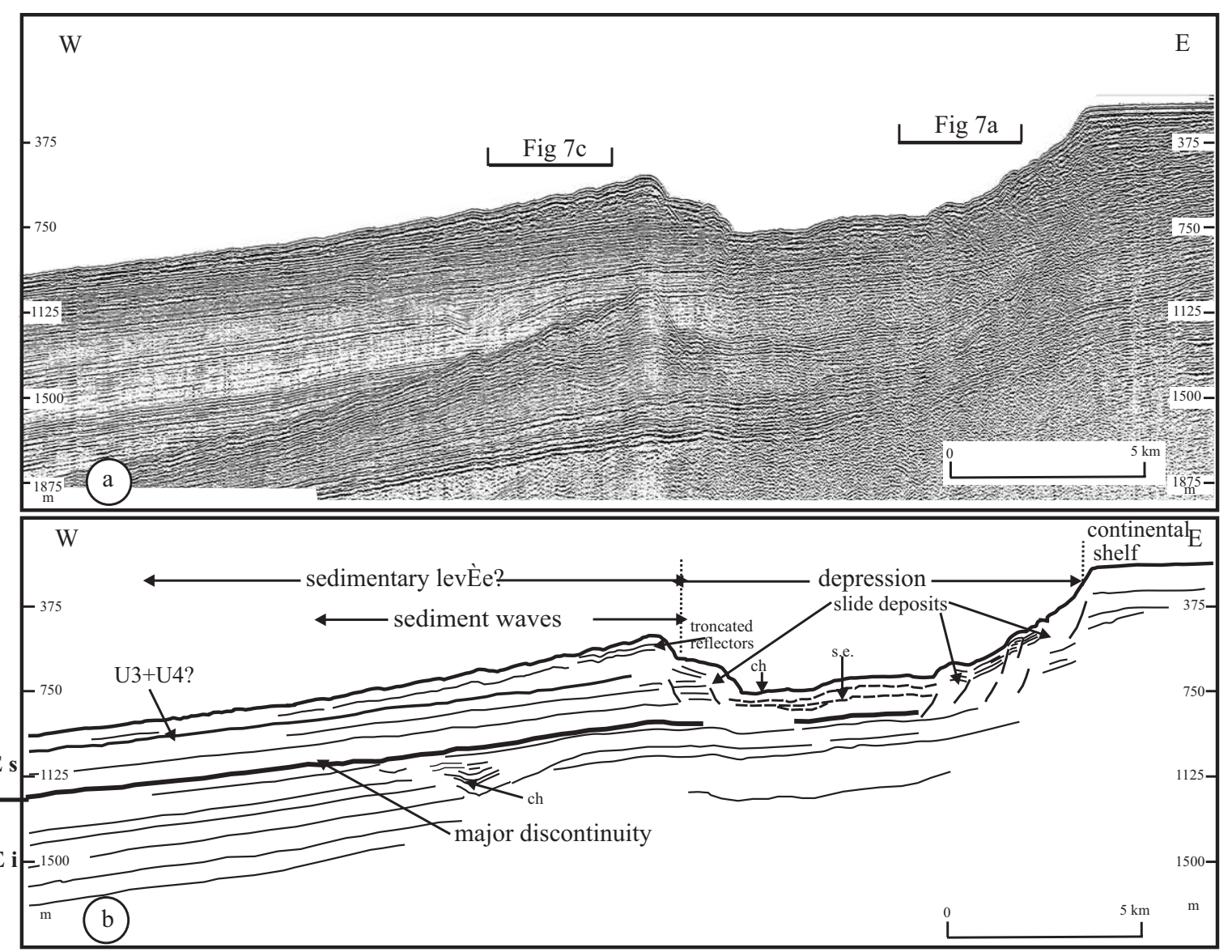

FIG. 5. - Itsr29 seismic profile crossing the western depression, location in Figure 4). a: seismic line; b: interpretation (s.e.: superimposed erosional surface; ch: channel; E.s: upper seismic units; E.i.: lower seismic units; U3+U4?: surficial seismic units probably similar to U3+U4 units defined in the northern part of the study area, cf. Figure 3). Location of figures $7 \mathrm{a}$ et $7 \mathrm{c}$.

north region and can be considered to their southern equivalent.

The undulating structures on the western flank of the relief (Fig. 5) correspond to the southern part of the wave field developing to the north (Fig. 2). Their dimensions are on average lesser. Unlike what was observed in the northern part, the wave internal geometry does not show any evidence of construction processes (Figs. $8 \mathrm{a}$ and $8 \mathrm{~b}$ ). The structures form as sedimentary packets limited by accidents (discontinuities or listric faults) and are more or less deformed as dissymmetrical folds thrusting upslope. More or less transparent seismic facies localised in a particular area suggest the presence of gas circulation that may favour instabilities.

These structures are interpreted to result from the deformation of the deposits by low-speed gravity flow. Their frequency and amplitude vary from large-spaced structures, with minor deformation (Fig. 8a) because of creeping processes or sediment compression around gas pipes, to structures with a greater deformation of the beds forming retrograding amalgamated slid packets (Figs. 7c and $8 \mathrm{c})$. The amplitude of the deformations decreases with the distance downslope (compare Figs. $8 \mathrm{c}$ and $8 \mathrm{a})$. The accidents enlightening the slide packets mainly affect the U3 unit and exceptionally the draping U4 unit. This confirms the present-day nil to low activity of the sliding as observed in the northern area.

\section{DISCUSSION}

\section{Morphology of the talus and upper continental slope: role of reworking processes, gravity ero- sion and construction processes}

The comparison of the talus and the upper continental margin indicates that the reworking process due to sediments sliding down seems to have been more active in the south than in the north. 

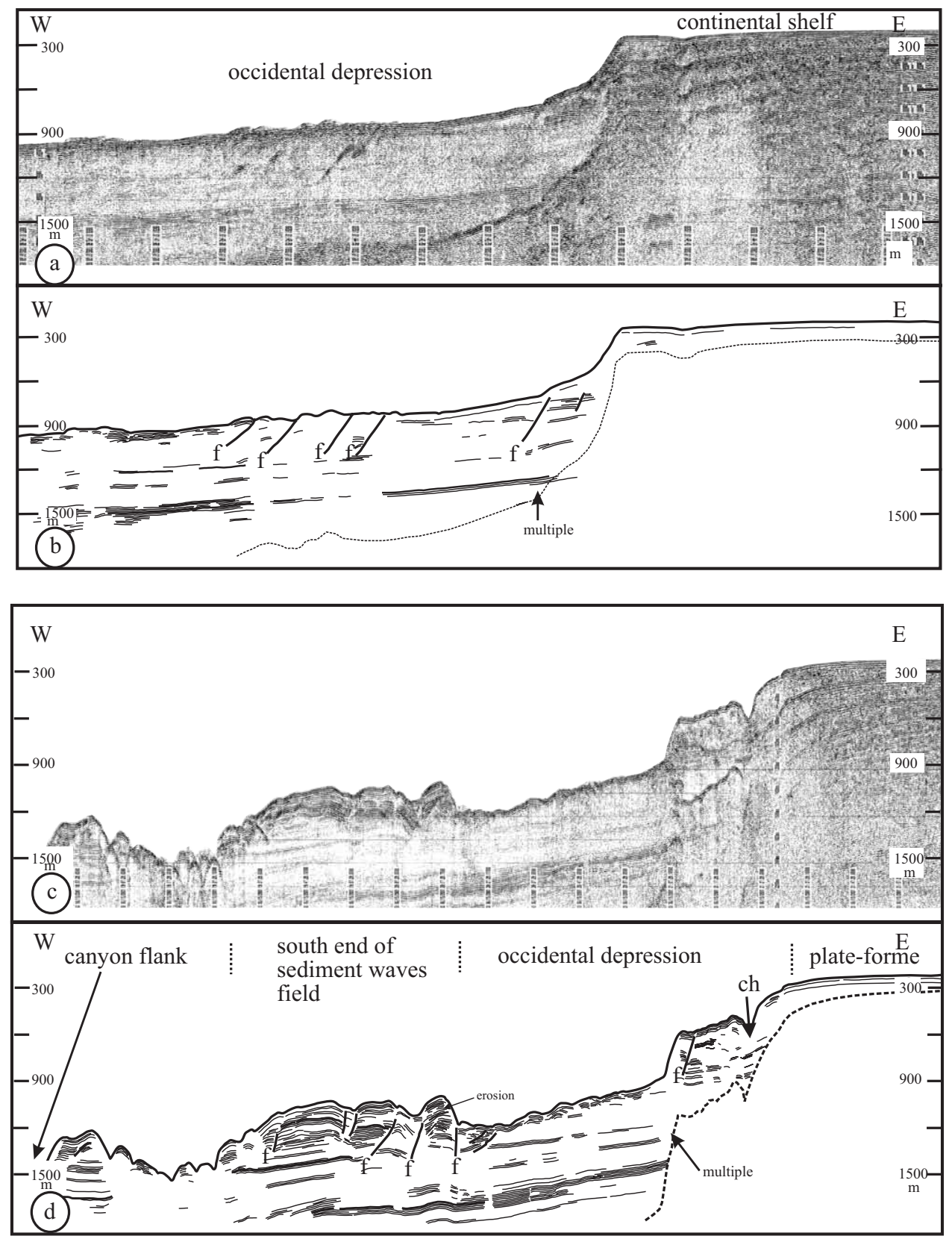

FIG. 6. - Itsr21 and itsr26 seismic lines, (location in Figure 4) showing deposit deformation in the western depression. a: profile itsr26; b: interpretation; c: profile itsr21; d: interpretation (f: listric faults, ch: meandering channel crossing the eastern depression, cf. 2 in Figure 4).

In the northern part, these processes are minor and usually involve creeping, compaction-subsidence or low amplitude slides. They generate structures with varying degrees of undulation in constructional processes that create migrating dune geometries of large amplitude.

In the southern part, deformation processes and gravity erosion are essentially responsible for the observed morphology. Indeed, there are no evidences of dynamic construction by currents either in wave-like structures (Figs. 7c and 8c) or in sedi- mentary relief (levee? Figure 5). The waves form on west to southwest dipping slopes only by deformation and reworking of sediments. These processes are probably more important and rapid than in the northern part, thus preventing the expression of construction processes, but they are less active.

In addition, the only sedimentary relief whose morphology is similar to a turbiditic levee modelled by waves borders the western depression to the west (Figs. 4 and 5). Though the waves covering the western flank do not reveal any geometry resulting from 


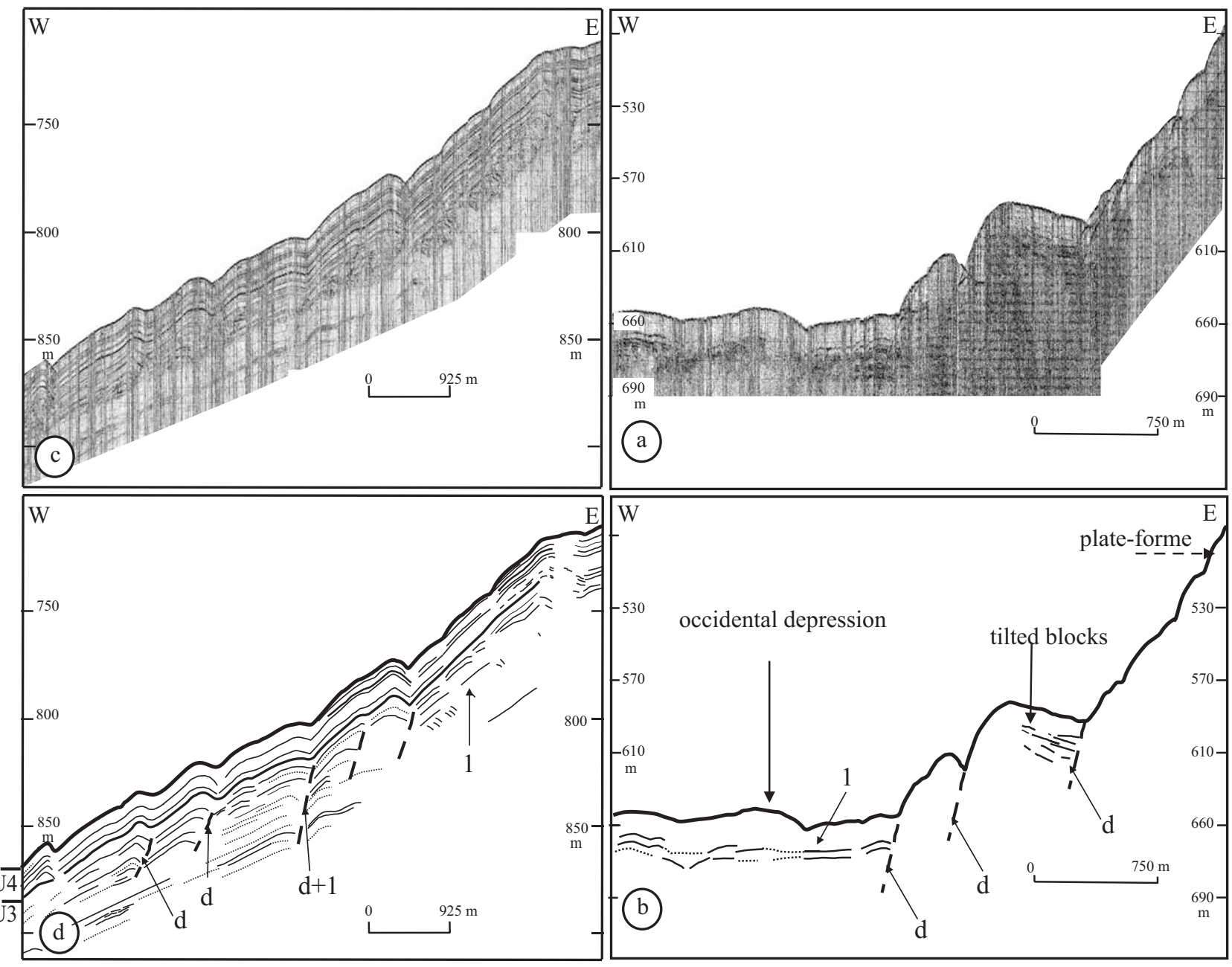

FIG. 7. - Details of itsd29 chirp profile (location in Figures 4 and 5). a: seismic profile crossing the western depression; b: interpretation, note the draping and transparent sediment cover and tilted packets of sediments in the eastern flank of the depression (d: discontinuities and/or micro-faults between the packets; 1: transparent deposits); c: seismic profile crossing the levee (?) and the wavy structures (d: discontinuities or micro-faults; 1 : strongly disturbed deposits).

the over-spilling of turbidite surges from the adjacent depression, the truncated reflectors on the western flank of the depression (Fig. 5) show that the apparent relief of the levee is the outcome of the formation of the depression by mass erosion processes. These processes expanding on south dipping slopes seem to result from detachment mechanisms of large sediment packets that slide down to the Capbreton canyon. Their morphological expressions are erosive scars at the origin of the north-south depression open toward the axial channel of the canyon.

Thus, the sedimentary forms observed in the study area are essentially a consequence of reworking and gravity erosion processes. The construction processes play a minor role as they are only involved in the development of the dune field of the northern area.

\section{Formation of the erosive depressions open toward the Capbreton canyon: mechanisms and age}

The erosive phase at the origin of the depressions, and the western one in particular, does not seem to correspond to a single and rapid erosive episode due to sediment slide but rather to a progressive erosive phase.

According to the seismic profiles, it could be a question of successive slides of sedimentary packets limited by listric faults with a retrogradation effect (Mulder and Cochonnat, 1996), as shown in Figures 5, 6 and 7a. However, as soon as a significant depression developed it could act as a privileged pathway for turbidity currents. These could either increase the erosion, prevent the deposit of sediments or even build meandering channels like the 

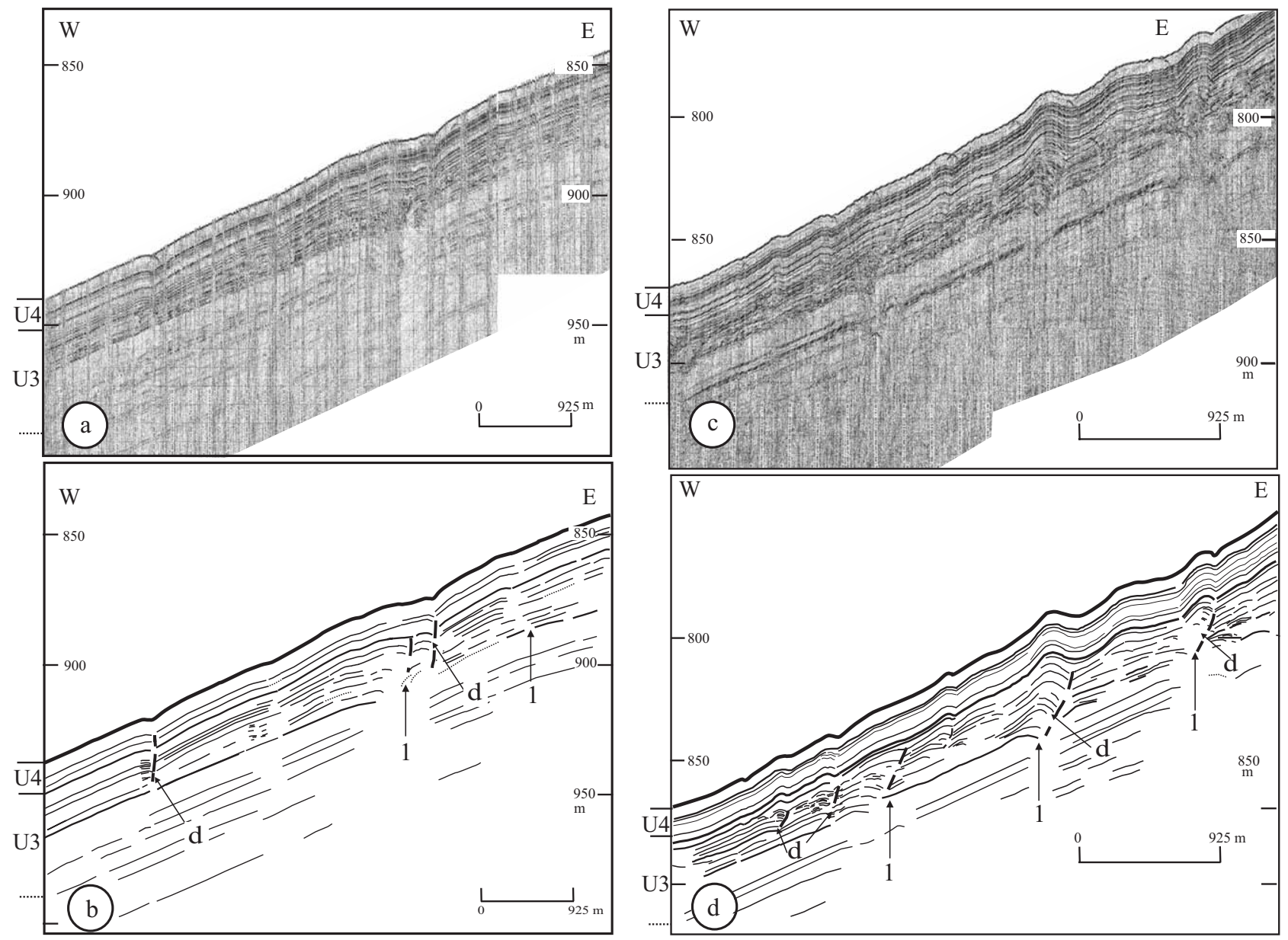

FIG. 8. - Details of itsd27 and itsd 28 chirp profiles (location in Figure 4). a: profile itsd27 showing very poorly developed wavy bedforms; b: interpretation; c: profile itsd28 showing more developed wavy bedforms; d: interpretation (d: discontinuities or micro-faults; 1 : disturbed deposits).

one visible in the eastern depression (Fig. 4). Since this phase, underlined by several stacked erosive surfaces (Fig. 5), the process activity is low or nonexistent. This is underlined by the presence of uniform deposits covering the bottom of the depression and draping the latest erosive surface (Fig. 7a). Nevertheless, the flanks of the depression might still have been recently affected by gravity destabilisation processes (Fig. 7a).

The erosive phase seems to have ended recently. Indeed, the transparent deposits draping the latest erosive surface visible on the Chirp profiles are about $10 \mathrm{~m}$ thick (Fig. 7a). Although in this region the sedimentation rates vary with the slope morphology, this event could be late Quaternary in age, meaning around 100,000 years BP. This figure corresponds to a sedimentation rate of $10 \mathrm{~cm}$ per 1000 years proposed for the Plio-Quaternary deposits of the south Aquitaine margin (Caralp, 1968 and 1971; Winnock, 1973; Duprat, 1983).

\section{Role of the Capbreton canyon}

The great depth of the Capbreton canyon favours the destabilisation of its flank and of the bordering continental slope. This explains the more important role of these processes in the sea-floor morphology of the south of the continental slope compared to its northern part. The steepest south and southwest slopes induce the deformation of the deposits and the development of sediment wave structures. Those dipping toward the canyon generate retrogressive erosion processes by detachment and sliding of sediment mass. These sediments reach the axial channel, where they are funnelled toward the depths. In addition, thanks to the depressions created by large slides, the turbidity currents initiated on the continental shelf converge toward the canyon through channels that are visible in these depressions. The canyon also induces the development of a drainage network on the upper slope through which the sedi- 
ments supplied from the shelf travel. However, the over-incision of the axial channel up to its head shows the upstream part of the system to be the major sediment supplier.

The alongshore currents combined with strong storms favour a N-S transfer of sediments on the inner continental shelf and allow a direct feeding of the upper part of the canyon located close to the shoreline. This was evidenced with the recognition of presentday turbiditic activity by Mulder et al. (2001), underlining the major role of the canyon in the transfer of sediments wherever the sea-level stands.

\section{Controlling factors of favourable periods of gravity reworking processes}

Three different factors control gravity reworking on the upper slope:

- large sediment supply periods, either linked to stronger erosion on the continent and generally synchronous to lowstands in the studied region (Cremer, 1983; Castaing et al., 1980) or related to a more active hydrodynamic on the shelf during highstands; both cases deal with a climatic control;

- sea level rise periods that could generate overpressures in deposits with increasing water column height;

- tectonic activity leading, during seismic activity periods, to the modification of the physical properties of the deposits.

The stratigraphic data available do not allow these factors to be discriminated. In the PlioQuaternary deposits of the northern part of the study area, the interbedding of draping deposits similar to unit U4 with beds with gravity deformations and depositional waves similar to unit U3 (Faugères et al., 2002) suggests the possible role of variations in supplies and/or the position of the sea-level. However, the change in the characteristics of the sedimentation at the base of U4 (thickness 12 to $15 \mathrm{~m}$, sedimentation rate $10 \mathrm{~cm} / 1000$ years), might be dated at about 120,000 to 150,000 years BP. U4 shows uniform draping sediments and is synchronous with major eustatic variations that have not been recorded in the geometry of the deposits. This makes the control of gravity reworking processes by eustatism and larger concomitant supplies unlikely. Thus, it is possible to consider that the tectonic activity plays a major role with, in particular, the diapirs present under the upper part of the margin, like those in the northern area mentioned above.

\section{CONCLUSION}

The study of the first set of seismic and bathymetric data acquired on the southern part of the Aquitaine continental slope highlights the importance of gravity-induced reworking-erosion in the sedimentary processes affecting this type of deep marine domain.

On the upper slope, far from the Capbreton Canyon influence, these processes are lightly active and, combined with deposit-construction processes they contribute to the development of sedimentary wave-like structures. Close to the canyon, they are more spectacular and fully responsible for the modelling of the sea-floor. On the west dipping slope they induce deformations within the deposits resulting from small-amplitude slides and mimicking sedimentary waves. On the steeper slope, dipping south toward the Capbreton Canyon, they are expressed as detachment mechanisms and large sliding packets of sediments vanishing in the canyon. These result in the erosive scar morphology at the origin of the N-S depressions in the axial channel of the Capbreton Canyon.

These structures show the great influence of reworking-erosive processes on the upper slope in the modelling of this part of the margin, and in the transfer of sediments to the depths.

\section{ACKNOWLEDGEMENTS}

The authors thank the crews of the R/V "Côte d'Aquitaine" (INSU) and R/V "Le Suroit" (IFREMER-GENAVIR). We are grateful to the different reviewers who helped to improve this study. This is the contribution number 1483 of the UMR-EPOC 5805 CNRS.

\section{REFERENCES}

Babonneau, N., B. Savoye, M. Cremer and B. Klein. - 2002. Morphology and architecture of the present canyon and channel system of the Zaire deep-sea fan. Mar. Pet. Geol., 19: 4, 445-467.

Baraza, J. and G. Ercilla. - 1996. Gas-charged sediments and large pockmarks-like features on the Gulf of Cadiz slope (SW Spain). Mar. Pet. Geol., 13, 2: 253-261.

Berné, S., B. Loubrieu et l'équipe Calmar embarquée. - 1999. Canyons et processus sédimentaires récents sur la marge occidentale du golfe du Lion. Premiers résultats de la campagne Calmar. C. R. Acad. Sci. Paris, 328: 471-477.

Boillot, G., P.A. Dupeuble, I. Hennequin-Marchand, M. Lamboy, J.P. Leprêtre and P. Musellec. - 1974. Le rôle des décrochements «tardi-hercyniens» dans l'évolution structurale de la marge continentale et dans la localisation des grands canyons sous-marins à l'ouest et au nord de la péninsule ibérique. Rev. 
Géogr. Phys, Géol. Dynam., (2): XVI -1, 75-86.

Boillot, G., L. Montadert, M. Lemoine and B. Biju-Duval. - 1984. Le golfe de Gascogne et les Pyrénées. In: G. Boillot (coord.), Les marges continentales actuelles et fossiles autour de la France. Masson, Paris.

Bouma, A.H. - 1985. Mississipi fan, Gulf of Mexico. In: A.H. Bouma, W.R. Normark and N.E. Barnes (eds.), Submarine Fans and Related Turbidite Systems, pp. 143-150, SpringerVerlag, New York.

Caralp, M. - 1968. Variations climatiques pléistocène dans le Golfe de Gascogne d'après les foraminifères planctoniques. Bull. Inst. Geol. Bassin d'Aquitaine, 5: 87-110.

Caralp, M. - 1971. Les foraminifères planctoniques du Pléistocène terminal dans le Golfe de Gascogne: interprétation biostratigraphique et paléoclimatique. Bull. Inst. Geol. Bassin d'Aquitaine, 11: 1-187.

Castaing, P., P. Cirac, M. Cremer, J.P. Tastet and O. Weber. - 1980. Influence des variations du niveau de la mer sur la sédimentation récente de la marge Aquitaine (Golfe de Gascogne). In :

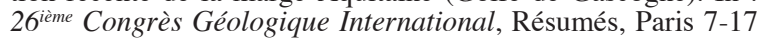
Juillet, vol II, (sections 6 à 12).

Cholet, J.B., B. Damotte, G. Grau, Y. Debyser and L. Montadert. 1968. Recherches préliminaires sur la structure géologique de la marge continentale du Golfe de Gascogne: commentaires sur quelques profils de sismique réflexion flexotir. Rev. Inst. Fr. Petr., 23: 1029-1045.

Cirac, P., J.F. Bourillet, R. Griboulard, A Normand, T. Mulder et l'équipe Itsas. - 2001. Le canyon de Capbreton: nouvelles approches morphostructurales et morphosédimentaires. Premiers résultats de la campagne Itsas. C.R. Acad. Sci., Paris, Series IIA, 332: 447-455.

Cirac, P., J.F. Bourillet, B. Loubrieu, M. Gaudin, M. Cremer and E. Gonthier. - 2002. Présentation morphostructurale et morphosédimentaire de la partie supérieure du canyon de Capbreton. $8^{\text {th }}$ International Symposium on Oceanography of the Bay of Biscay. Book of Abstracts, p. 44.

Cremer, M. - 1983. Approches sédimentologique et géophysique des accumulations turbiditiques. L'éventail profond du CapFerret (Golfe de Gascogne), la série des grés d'Annot (Alpes de Haute Provence). Ph. D. Thesis, Univ. Bordeaux.

Dauvillier, A. - 1961. L'origine du gouf de Capbreton. Sciences, Paris, 15: 47-55.

Duprat, J. - 1983. Les foraminifères planctoniques du quaternaire terminal d'un domaine péricontinental (Golfe de Gascogne, côtes Ouest Ibériques, mer d'Alboran): écologie-biostratigraphie. Bull. Inst. Geol. Bassin d'Aquitaine, 33: 71-150.

Ercilla, G., B. Alonso, F. Estrada, F.L. Chiocci, J. Baraza and M. Farran. - 2002. The Magdalena Turbidite System (Caribbean Sea): present-day morphology and architecture model. Mar. Geol, 185: 303-318.

Faugères, J.C., E. Gonthier, T. Mulder, N. Kenyon, P. Cirac, R. Griboulard, S. Berné and Lesuavé, R. - 2002. Multi-process generated sediment waves on the Landes Plateau (Bay of Biscay, North Atlantic). Mar. Geol., 182: 279-302.

Gardner, J.V., D.B. Prior and M.E. Field. - 1999. Humboldt slide a large shear-dominated retrogressive slope failure. Mar. Geol., 154: $323-338$

Greene, H.G., N.M. Maher and C.K. Paull. - 2002. Physiography of the Monterey Bay National Sanctuary and implications about continental margin development. Mar. Geol., 181: 55-82.

Hill, K., K. Moran and S.M. Blasco. - 1982. Creep deformation of slope sediments in the Canadian Beaufort sea. Geo-Mar. Lett., 2: $163-170$.

Hovland, M. and A.G. Judd. - 1988. The ecology of pockmarks and seepages. In: M. Hovland and A.G. Judd (eds.), Seabed Pockmarks and Seepages: Impact on Geology, Biology and the Marine Environment, pp 227-245. Graham and Trotman, London.

Johnson, H.D. and C.T. Baldwin. - 1996. Shallow clastic seas. In: H.G. Reading (ed.), Sedimentary Environments: Processes, Facies and Stratigraphy, pp. 232-280. Blackwell.

Kenyon, N.H., R.H. Belderson and A.H. Stride. - 1978. Channels, canyons and slump folds on the continental slope between South-West Ireland and Spain. Oceanol. Acta, 1: 369-380.

Kieken, M. - 1973. Evolution de 1'Atlantique au cours du Tertiaire. Bull. Soc. Géol. France, 7, XV, 1: 1-44.
Le Moigne, M. - 1999. Compréhension des mécanismes de formation des pockmarks sur la pente continentale du Golfe de Guinée. Mémoire de DEA: Géologie, géophysique et géochimie sédimentaire, (Université de Paris XI, Université des Sciences et Technologies de Lille, Laboratoire Environnements Sédimentaires IFREMER, Brest, Elf Gabon).

Lewis, K.B. -1971 . Slumping on a continental slope inclined at $1^{\circ}$ $4^{\circ}$. Sedimentology, 16: 97-110.

Lowe, D.R. - 1982. Sediment gravity flows: II. Depositional models with special reference to the deposits of high-density turbidity currents. J. Sed. Petr., 52: 279-297.

Normark, W.R. and D.J.W. Piper. - 1991. Initiation processes and flow evolution of turbidity currents: implications for the depositional record. In: SEPM, Society for Sedimentary Geology (eds.), From Shoreline to Abyss, SEPM Special Publication, 46: 207-230.

Martinsen, O.J. - 1989. Styles of soft-sediment deformation on a Namurian delta slope, Ireland. In: M.K.G. Whateley and K.T. Pickering (eds.) Deltas: Sites and Traps for Fossil Fuels. Geol. Soc. Lond., Sp. Pub., 41: 167-177.

Martinsen, O.J. and B. Bakken. - 1990. Extensional and compressional zones in slumps and slides in the Namurian of Country Clare, Ireland. J. Geol. Soc. Lond., 147: 153-164.

Mulder, T. and P. Cochonat. - 1996. Classification of offshore mass movements. J. Sediment. Res., 66: 43-57.

Mulder, T., O. Weber, P. Anschutz, F.J. Jorissen and J.M. Jouanneau, J.M. - 2001. A few months-old storm-generated turbidite deposited in the Capbreton Canyon (Bay of Biscay, SW France). Geo-Mar. Lett., 21: 149-156.

Nesteroff, W., S. Duplaix, J. Sauvage, F. Mélières, Y. Lancelot and E. Vincent. - 1968. Conditions de sédimentation dans le Gouf de Cap Breton. C.R. Acad. Sci., 266: 68-71.

Normark, W.R., G.R. Hess, D.A.V. Stow and A.J. Bowen. - 1980 Sediment waves on the Monterey fan levees: a preliminary physical interpretation. Mar. Geol., 37: 1-18.

Nittrouer, C.A. and L.D. Wright. - 1994. Transport of particules across continental shelves. Rev. Geophys., 32: 85-113.

O’Leary, D.W. and E. Laine. - 1996. Proposed criteria for recognizing intrastratal deformation features in marine high resolution seismic reflection profiles. Geo-Mar. Lett., 16: 305-312.

Schoeffler, J. - 1965. Le «gouf» de Capbreton de l'Eocène inférieur à nos jours. In: W.F. Whittard and R. Bradshaw (eds.), Submarine Geology and Geophysics, pp. 265-270. Butterworths, London.

Shepard, F.P. and N.F. Marshall. - 1978. Currents in Submarine Canyons and Other Sea Valleys. In: D.J. Stanley and G. Kelling (eds.), Sedimentation in submarine canyons, fans, and trenches, pp. 3-14. Hutchinson \& Ross, Dowden.

Stanley, D.J. and G.T. Moore. - 1983. The Shelf Break: Critical Interface on Continental Margin. S.E.P.M., Spec. Publ., 33: 467 p.

Stride, A.H., J.R. Curray, D.G. Moore and R. Belderson. - 1969. Marine geology of the Atlantic continental margin of Europe. Philosl. Trans. R. Soc. London., A, 264: 31-75.

Swift, D.J.P., G.F. Oertel, R.W. Tillman and J.A. Thorne. - 1991. Shelf sand and Sandstone Bodies: Geometry, Facies and Sequence Stratigraphy, Blackwell, Int. Ass. Sediment., Spec. Publ., 14: 3-31.

Syvitsky, J.P.M., D.C. Burrell, and J.M. Skei. - 1987. Fjords: Processes and Products. Springer Verlag, New York.

Valery, P., J.R. Delteil, A. Cottençon, L. Montadert, B. Damotte and J.P. Fail. - 1971. La marge continentale d'Aquitaine. In: Histoire Structurale du Golfe de Gascogne, Publications de l'I.F.P., Collection colloques et séminaires 22, Editions Technip, tome 1, Paris, IV.8-1/IV, pp.8-23.

Viana, A.R., J.C. Faugères and D.A.V. Stow. - 1998. Bottom current controlled sand deposits - a review from modern shallowto deep-water environments. Sediment. Geol., 115: 53-80.

Winnock, E. - 1973. Exposé succinct de l'évolution paléogéologique de l'Aquitaine. Bull. Soc. Géol. Fr., 7: XV, 1, $8-12$.

Whitham, A.G. - 1993. Facies and depositional processes in an Upper Jurassic to Lower Cretaceous pelagic sedimentary sequence, Antarctica. Sedimentology, 40: 331-349.

Received July 19, 2002. Accepted November 24, 2004. 